\title{
Aktualisasi Nilai-Nilai Pendidikan Islam dalam Merevitalisasi Pemahaman Moderasi pada Lembaga Pendidikan di Indonesia (Analisis Praksis dan Kebijakan)
}

\author{
Nashuddin \\ Universitas Islam Negeri (UIN) Mataram \\ email: nashuddin@uinmataram.ac.id
}

\begin{abstract}
True education makes people more respectful of differences and understanding diversity. Schools offer openness, moderation, and peace, not closure, extremism, and violence. But in reality on the ground, schools are actually not sterile from the outbreak of intolerance and the virus of radicalism. A number of studies show at one conclusion - which is almost agreed on - that intolerance in the world of education is increasing. Starting from rejecting leaders of different religions, do not want to respect the flag, the veil obligation, to those who openly support the khilafah. The entry of intolerance is assessed entering from three doors. First, teacher. Teacher understanding often determines how students behave and act. Second, the curriculum which is still dogmatic-doctrinaire does not provide space for dialogue and imagination. Third, extra activities are loaded with certain ideologies. In this context, it is necessary to return to voice moderation in schools. Attitudes that are not extreme right, always negate everything; nor extreme left, accommodating anything from outside; but rather be selective-accommodating. Teaching selective-accommodative attitude to students, has its own challenges. Not to mention the tendency of religious ways that are practical, instant, and do not want to be complicated, on the one hand; plus the penetration of social media - borrowing the language of Tom Nicholas (Death of Expertise, 2017) - there is a democratization of information, everyone is equal in it, on the other hand. Making moderation mainstreaming projects in schools has its challenges.
\end{abstract}

Keywords: Actualization, Islamic Education Institutions, Moderation, Praxis, Policy

\section{ABSTRAK}

Pendidikan sejatinya membuat manusia lebih menghargai perbedaaan dan memahami keragaman.Sekolah mengarjakan keterbukaan, moderasi, dan kedamaian, bukan ketertutupan, ekstrim, dan kekerasan.Akan tetapi fakta di lapangan, sekolah justru tidak streril dari wabah intoleransi dan virus radikalisme. Sejumlah penelitian menunjukkan pada satu kesimpulan -yang hampir disepakati-bahwa intoleransi dalam dunia pendidikan semakian meningkat. Mulai dari menolak pemimpin beda agama, tidak mau menghormat bendera, pewajiban jilbab, sampai yang terang-terangan mendukung khilafah. Masuknya intoleransi dinilai masuk dari tiga pintu. Pertama, guru. Pemahaman guru sering menentukan cara bersikap dan bertindak siswa. Kedua, kurikulum yang masih dogmatis-doktriner, tidak memberikan ruang untuk berdialetika dan berimajinasi. Ketiga, kegiatan ekstra yang sarat dengan ideologi tertentu. Dalam konteks inilah, perlu kembali menyuarakan moderasi di sekolah. Sikap yang tidak ekstrim kanan, selalu menegasikan semuanya; juga tidak ekstrim kiri, menampung apapun dari luar; melainkan bersikap selektif-akomodatif. Mengajarkan sikap selektifakomodatif kepada peserta didik, mendapat tantangan tersendiri. Belum lagi adanya kecenderungan cara beragama yang praktis, instan, dan tidak mau ribet, di satu sisi; di tambah penetrasi media sosial -meminjam bahasa Tom Nicholas (Matinya Kepakaran, 2017) - terjadi demokratisasi infomasi, semua orang setara di dalamnya, di sisi lain. Membuat proyek pengarusutamaan moderasi di sekolah mendapat tantangannya tersendiri.

Kata kunci: Aktualisasi, Lembaga Pendidikan Islam, Moderasi, Praksis, Kebijakan 


\begin{tabular}{|c|c|c|}
\hline $\begin{array}{c}\text { First Receive: } \\
\text { 4 June 2020 }\end{array}$ & $\begin{array}{c}\text { Revised: } \\
\text { 7 June 2020 }\end{array}$ & 25 June 2020 \\
\hline $\begin{array}{c}\text { Final Proof Recieved: } \\
\text { 28 June 2020 }\end{array}$ & Published: \\
30 June 2020 \\
$\begin{array}{c}\text { Nashuddin, (2020). Aktualisasi Nilai-Nilai Pendidikan Islam dalam Merevitalisasi } \\
\text { Pemahaman Moderasi pada Lembaga Pendidikan di Indonesia. Schemata, 9 (1), } \\
\text { 33-52. }\end{array}$ \\
\hline
\end{tabular}

\section{PENDAHULUAN}

Pendidikan Islam yang saat ini kita kenal telah berkembang ketika mulainya tradisi belajar kepada ulama-ulama yang umumnya adalah pedagang, yang sekaligus pembawa Islam ke Indonesia. Para murid datang menemui guru untuk menanyakan hal-hal yang ingin diketahui. Kemudian bentuk ini berlanjut dengan sistem langgar, dimana para murid dan guru baik dalam bentuk sorogan maupun dalam bentuk halaqah—dari sini kemudian muncul bentuk pendidikan pesantren yang dilanjutkan dengan sistem kelas, yang diperkenalkan penjajah Belanda.

Pembicaraan Islam sebagai suatu agama dan seperangkat ajaran, serta aktualisasi nilainilainya karena Islam merupakan tuntunan dan pedoman bagi pemeluknya dalam menjalani kehidupan, baik dalam konteks hubungan manusia dengan sesama manusia, hubungan manusia dengan alam dan hubungan manusia dengan tuhannya. Idealitas tersebut menempati ruang utama dalam khazanah pertumbuhan dan perkembangan penelaahan tentang Islam dari zaman ke zaman. Idealitas Islam tersebut merupakan visi dan misi yang selalu mendatangkan inspirasi bagi para pemikir Islam untuk menerjemahkan dan merealisasikan makna di atas. Meskipun demikian, inspirasi-inspirasi yang tertuang dalam nalar Islam justru belum dianggap mampu memberikan jawaban atas persoalan umat. Bahkan nalar Islam hadir, tetapi justru terlepas dari masalah nyata yang dihadapi umat Islam. ${ }^{1}$

Dalam sejarahnya, pendidikan Islam telah berkembang sejak era kenabian, sejak era ini, pemahaman-pemahaman tentang Islam disampaikan melalui kutbah, dialog, dan forumforum diskusi di masjid. Pada era berikutnya, nalar Islam berkembang seiring proses ekspansi peradaban Islam yang semakin meluas. Pada era itulah Islam ditelaah dalam berbagai dimensi. Dimensi teologi terdapat nama-nama seperti Abu al-Hasan al-Asyari dan Abd al-Jabbar. Sedangkan dimensi filsafat mencetuskan nama-nama seperti al-Kindi, Ibn Sina (Avicenna), Ibn Rusyd (Averroes) dan al-Farabi, dimensi hukum melahirkan empat mazhab fiqih, (Syafi'i, Maliki, Hanafi, dan Hambali) sedangkan dimensi sufistik melahirkan al-Ghazali. Nama-nama di atas sekedar sebagai contoh dalam menggambarkan dinamika intelektual muslim pada zamannya.

${ }^{1}$ Zubri, Studi Islam Dalam Tafsir Sosial Telaah Sosial Gagasan Keislaman Fazlur Rabman dan Muhammed Arkoun, (Yogyakarta: Bidang Akademik. UIN Sunan Kalijaga, 2008) hlm. 2-3.

Copyright $\mathbb{C} 2020$ Schemata Journal

Available online at http:/ /journal.uinmataram.ac.id/index.php/schemata 
Namun dalam konteks kekinian, pendidikan Islam telah dihadapkan dengan tantangan zaman, yakni zaman perkembangan serta kemajuan pemikiran yang termanifestasi dalam ilmu pengetahuan, sosial, budaya dan teknologi, lalu apakah pemikiran saat ini akan terus berjalan dalam wilayah yang sama, sedangkan perkembangan terus menuntut manusia untuk maju. Watak zaman menuntut manusia untuk melakukan pembaharuan, karena setiap zaman yang datang pasti membawa suatu hal yang baru yang berbeda dari kondisi masa lalu. ${ }^{2}$

Di samping itu, pendidikan Islam harus di lihat dari dimensi aktualisasi nilai-nilainya sehingga mampu merevitalisasi pemahaman moderasi di tengah peradaban yang serba modern serta bagaimana aktualisasi nilai-nilai keislaman dalam dimensi lembaga pendidikan dan kebijakan yang telah diterapkan.Maka untuk melihat dimensi aktualisasi dari kebijakan pemerintah dalam aktualisasi nilainya, perlu di telaah secara mendalam melalui tulisan ini sehingga mampu menemukan titik temu di mana aktualisasi nilai-nilai keislaman serta kebijakannya dalam lembaga pendidikan.

\section{METODE PENELITIAN}

Adapun metode penelitian kajian pustaka atau studi kepustakaan yaitu berisi teoriteori yang relevan dengan masalah - masalah penelitian. Adapun judul penelitian ini adalah "Aktualisasi nilai-nilai pendidikan Islam dalam merevitalisasi pemahaman moderasi pada lembaga pendidikan di Indonesia". Pada bagian ini dilakukan pengkajian mengenai konsep dan teori yang digunakan berdasarkan literatur yang tersedia, terutama dari artikel-artikel yang dipublikasikan dalam berbagai jurnal ilmiah. Kajian pustaka berfungsi untuk membangun konsep atau teori yang menjadi dasar studi dalam penelitian. ${ }^{3}$ Kajian pustaka atau studi pustaka merupakan kegiatan yang diwajibkan dalam penelitian, khususnya penelitian akademik yang tujuan utamanya adalah mengembangkan aspek teoritis maupun aspek manfaat praktis ${ }^{4}$. Sehingga dengan menggunakan metode penelitian ini penulis dapat dengan mudah menyelesaikan masalah yang hendak diteliti.

Dilihat dari jenis penelitiannya, adapun jenis penelitian yang digunakan dalam penelitian ini adalah penelitian kepustakaan atau library research ${ }^{5}$, yakni penelitian yang dilakukan melalui mengumpulkan data atau karya tulis ilmiah yang bertujuan dengan obyek penelitian atau pengumpulan data yang bersifat kepustakaan, atau telaah yang dilaksanakan untuk memecahkan suatu masalah yang pada dasarnya tertumpu pada penelaahan kritis dan mendalam terhadap bahan-bahan pustaka yang relevan. Sebelum melakukan telaah bahan

${ }^{2}$ Ibid.,hlm. 8.

${ }^{3}$ V.Wiratna Sujarweni,Metodeologi Penelitian ( Yogyakarta : Pustaka Baru Perss, 2014), h.57..

${ }^{4}$ Sukardi,Metodologi Penelitian Pendidikan Kompetensi dan Praktiknya (Jakarata : PT Bumi Aksara,2013), h.33

5 Fithri Dzakiyyah,’Jenis Penelitian", (On-Line),tersedia dihttps://hidrosita.wordpress.com (5 Agustus 2017)

Copyright (C2020 Schemata Journal

Available online at http:/ /journal.uinmataram.ac.id/index.php/schemata 
pustaka, peneliti harus mengetahui terlebih dahulu secara pasti tentang dari sumber mana informasi ilmiah itu akan diperoleh. Adapun beberapa sumber yang digunakan antara lain; bukubuku teks, jurnal ilmiah,refrensi statistik, hasil-hasil penelitian dalam bentuk skripsi, tesis, desertasi,dan internet, serta sumber-sumber lainnya yang relevan ${ }^{6}$, b. Sifat penelitian Dilihat dari sifatnya, maka penelitian ini termasuk penelitian deskriptif, penelitian deskriptif berfokus pada penjelasan sistematis tentang fakta yang diperoleh saat penelitian dilakukan ${ }^{7}$.

\section{HASIL DAN PEMBAHASAN}

\section{a. Pendidikan Islam}

Islam memiliki ragam dimensi, salah satu dimensi yang ada di dalam agama Islam adalah dimensi ajaran atau doktrin. Dimensi ini menjadi titik utama pengembangan Islam di masyarakat dan dilakukan melalui dua pola yang saling terkait dan menimbulkan sebab-akibat, yaitu pola doktrinasi dan pola diskursif. Pola pertama mengidealkan kekuatan struktur objektivitas internalnya, sedangkan pola kedua mengidealkan kekuatan struktur rasionalitas eksternalnya. Dalam konteks doktrinasi, pendidikan Islam membentuk identitas keagamaan yang menjamin keberlansungan subtansi, fungsi, dan peran agama bagi penganutnya. Sebaliknya dalam konteks diskursif, pendidikan Islam membentuk rasionalitas keagamaan yang menjamin tegaknya konstruksi argumentasi subtansi, fungsi dan peran agama bagi masyarakat. Selanjutnya konteks ini membentuk jati dirinya pada lembaga-lembaga pendidikan Islam, baik dalam bentuk formal maupun non formal dalam upayanya mempertahankan sekaligus menjadi sumber dan proses inspirasi dinamika Islam di dalam masyarakat. ${ }^{8}$

Dalam pandangan Khoirudin Nasution, pendidikan Islam berkembang dari sorogan dan halaqah di rumah-rumah para alim ke sistem kuttab ${ }^{9}$ kemudian ke masjid-masjid dan berlanjut menjadi sistem madrasah. Dari tingkatan masjid ini sebagian murid melanjutkan pendidikan ke jenjang yang lebih tinggi, madrasah ${ }^{10}$. Pengertian madrasah di sini tidak sama dengan madrasah dalam pengertian madrasah pendidikan Islam Indonesia. Adapun pendidikan Islam berlanjut ke masjid menjadi pusat pendidikan dengan sistem halaqah. Dapat disebutkan bahwa pada tingkatan lembaga masjid ini

${ }^{6}$ Anwar Sanusi, Metodologi Penelitian Bisnis,(Jakarta : Salemba Empat,2016), h.32

${ }^{7}$ Anwar sanusi,Ibid.h.13

${ }^{8}$ Ibid., blm.1.

${ }^{9}$ Kuttab yakni sejenis tempat untuk. mengajarkan baca-tulis, dan kuttab juga sebagai tempat untuk mengajarkan Al-Qur'an dan dasar-dasar agama Islam.Kuttab ini memiliki dua pembagian.Pertama, kuttab sekular memiliki pengertian sebagai tempat diajarkannya tata bahasa, sastra dan aritmatika, sedangkan yang kedua, kuttab agama yang memiliki arti lebih khusus yakni tempat mempelajari materi agama. Lihat Khoirudin Nasution, dalam buku Pengantar Studi Islam, (Yogyakarta: ACadeMIA TAZZAFA, 2012), hlm. 62.

${ }^{10}$ Madrasah disini memiliki pengertian yang berbeda, dari pengertian pendidikan Islam yang ada di Indonesia.Madrasah yang dimaksud disini berarti pendidikan tinggi.Namun ada juga ilmuan yang menyebut bahwa bentuke awal lembaga pendidikan tinggi Islam adalab al-Jami'ah dari lembaga masjid Jami' tempat berkumpul orang banyak. Lihat Khoirudin Nasution, Pengantar Studi Islam. Lihat juga Ishak Hariyanto, blm. 2 
merupakan lanjutan dari kuttab. Kemudian kalau dilihat dari perkembangannya selama Tahun 750-1258 M merupakan masa kejayaan Muslim. Sementara pasca itu menjadi masa keruntuhan Muslim sekaligus masa kejayaan Eropa. ${ }^{11}$

Dalam konteks Indonesia, pendidikan Islam dimulai dengan tradisi belajar kepada ulama-ulama yang umumnya adalah pedagang, yang sekaligus pembawa Islam ke Indonesia. Para murid datang menemui guru untuk menanyakan hal-hal yang ingin diketahui. Kemudian bentuk ini berlanjut dengan sistem langgar. Di mana para murid dan guru baik dalam bentuk sorogan maupun dalam bentuk halaqah dari sini kemudian muncul bentuk pendidikan pesantren yang dilanjutkan dengan sistem kelas, yang diperkenalkan penjajah Belanda. Pembicaraan Islam sebagai suatu agama dan seperangkat ajaran, karena Islam merupakan tuntunan dan pedoman bagi pemeluknya dalam menjalani kehidupan, baik dalam konteks hubungan manusia dengan sesama manusia, hubungan manusia dengan alam dan hubungan manusia dengan Tuhannya. Idealitas tersebut menempati ruang utama dalam khazanah pertumbuhan dan perkembangan penelaahan tentang Islam dari zaman ke zaman. Idealitas Islam tersebut merupakan visi dan misi yang selalu mendatangkan inspirasi bagi para pemikir Islam untuk menerjemahkan dan merealisasikan makna di atas. Meskipun demikian, inspirasiinspirasi yang tertuang dalam pendidikan Islam justru belum dianggap mampu memberikan jawaban atas persoalan umat. Bahkan pendidikan Islam hadir, tetapi justru terlepas dari masalah nyata yang dihadapi umat Islam. ${ }^{12}$

Pendidikan atau kajian Islam, baik yang menyangkut ajaran atau nilai Islam secara dogmatis maupun praktis bermanfaat untuk menilai tata nilai Islam itu sendiri bagaimana umat Islam merefleksikan nilai keagamaan dalam kehidupan yang nyata.Pendidikan tentang nilai-nilai Islam melahirkan kritik yang mendalam tentang Islam sebagai sebuah ajaran yang diberikan Allah kepada hamba-Nya untuk memperoleh kebahagiaan hidup di dunia dan keselamatan hidup di akhirat. Kritik tersebut mampu mendorong tumbuhnya kesadaran dan keyakinan absolut tentang kebenaran Islam, dan bagi mereka yang sengaja mencari titik-titik tertentu untuk dikonfrontir dengan nilai keduniaan akan menemukan sisi pandang yang penuh dengan kecurigaan terhadap kebenaran Islam. Dalam aspek perilaku umat Islam yang diasumsikan sebagai cerminan nilai Islam dalam tataran sosial keagamaan, pendidikan Islam akan melahirkan kemajemukan prilaku keagamaan yang sangat khas dan penuh makna, sehingga sadar atau tidak terkadang ditemukan perilaku umat Islam yang sepintas bertentangan dengan

${ }^{11}$ Dalam sejarahnya perkembangan studi Islam di dunia Barat terjadi persentuhan Islam dengan Barat melalui fase ketika Islam memegang kejayaan dan menjadi pusat ilmu pengetabuan, teknologi dan kebudayaan dan juga fase ketika Islam jatub dan runtuh, sementara dunia Barat mulai jaya dan menjadi pusat ilmu teknologi dan kebudayaan. Khoirudin Nasution, Pengantar.., hlm. 63.

${ }^{12}$ Ishak Hariyanto, "Nalar islam Kontemporer Mubammed Arkoun” (Tesis Pascasarjana UIN Sunan Kalijaga Yogyakarta, 2015), hlm. 3. 
Islam atau bahkan bertentangan dengan Islam, realitas yang kurang dapat dipahami berdasarkan pendekatan-pendekatan ilmiah. ${ }^{13}$

Salah satu kritik yang dialamatkan pada kajian Islam di IAIN/UINmisalnya adalah lemahnya penguasaan metodologi, terutama metodologi kajian historis-empiris.Mata kuliah Metode PendidikanIslam merupakan pengantar tentang metodologi kajian Islam, baik secara doktriner maupun secara historis. Hal ini sangat penting, karena pada umumnya metodologi kajian doktriner dan empiris diberikan secara terpisah yang tidak ada hubungannya satu sama lain. Dalam pendidikan ilmu agama (Religionswissenschaft) terdapat dua bentuk kajian Islam: secara substantif dan fungsional, atau dalam istilah lain secara doktriner dan historis-empiris. Bila metodologi kajian doktriner, adalah ulumul Qur'an, ulumul Hadits dan ushul fiqh, maka metodologi kajian historis-empiris, adalah metode penelitian sosial dan sejarah. Dengan pengintegrasian kedua metodologi ini diharapkan ada kemajuan dalam pendidikanIslam di Indonesia.Selama ini kajian Islam di Indonesia lebih menekankan aspek doktriner dan normatif, maka perlu diimbangi dengan kajian historis-empiris.Untuk mendukung hal ini, perlu juga diupayakan kedekatan (reapproachement) antara ilmu-ilmu agama Islam dengan ilmu-ilmu sosial dan humaniora.Hal ini bisa dilakukan dengan menjadikan ilmu-ilmu sosial dan humaniora sebagai bidang pendidikan pelengkap (minor) bagi kajian Islam.

Pendidikan Islam dari segi tingkatan kebudayaan, setiap agama memiliki nilai universal secara kultural. Salah satu prinsip teori fungsional menyatakan bahwa segala sesuatu yang tidak berfungsi akan lenyap dengan sendirinya. Karena sejak dulu hingga sekarang agama dengan tangguh menyatakan eksistensinya, berarti agama mempunyai dan memerankan sejumlah peran dan fungsi di masyarakat. ${ }^{14}$ Oleh karena itu, secara umum pendidikan Islam menjadi penting karena agama termasuk Islam memerankan sejumlah peran dan fungsi di masyarakat.Menurut Harun Nasution dalam simposium nasional yang ketiga menyatakan bahwa persoalan yang menyangkut usaha perbaikan pemahaman dan penghayatan agama terutama dari sisi etika dan moralitasnya kurang mendapat tempat memadai.Lebih lanjut, situasi keberagamaan di Indonesia cenderung menampilkan kondisi keberagamaan yang legalistik dan formalistik. Agama "harus" di manifestasikan dalam bentuk ritualformal, sehingga muncul formalisme keagamaan yang lebih mementingkan "bentuk" daripada "isi". Kondisi seperti itu menyebabkan agama kurang dipahami sebagai perangkat paradigma moral dan etika yang bertujuan membebaskan manusia dari kebodohan, keterbelakangan dan kemiskinan. ${ }^{15}$

Dinamika intelektual dalam Islam, pada dasarnya, merupakan watak dan ciri khas ajaran Islam. Hadits banyak memuat postulat-postulat yang mendorong kaum muslimin untuk mencarl ilmu

${ }^{13}$ M.C. Riflecks, Sejarah Indonesia Modern, (Yogyakarta: Gadjah Mada University Press, 1991).

${ }^{14}$ Djamari, Agama dalam Perspektif Sosiologi, (Bandung: Alfabeta, 1993), hlm. 25.

${ }^{15}$ Dalam pengantar simposium Nasional yang diselenggarakan oleh Forum Komunikasi Mahasiswa Pascasarjana (FKMP) LAIN Syarif Hidayatullah Jakarta, tanggal 6 agustus 1998 di Pusat Pengkajian Islam dan Masyarkat (PPIM). 
dengan cara membaca dan meneliti, walaupun sampai ke negeri Cina. Postulat-postulat seperti itulah yang nendorong kaum muslimin generasi pertama (salaf) menghasilkan karya-karya monumental dalam berbagai aspek pemikir-an keagamaan, seperti ilmu-ilmu al-Quran dan tafsir, ilmu-ilmu badis, figh, filsafat, dan kalam. Lahirnya karya-karya monumental tersebut menjadi masa keemasan bagi umat Islam, (the golden age/'asr al-zhahab). Setelah masa itu berlalu, datanglah masa kemunduran; bidang pemikiran membeku, bidang politik mengalami disintegrasi, di bidang sosial dan moral merajalela, sehingga kesemuanya itu sangat memudabkan musuh-musuh Islam memporakporandakan tatanan masyarakat Islam yang sudah mapan. Terlebih lagi setelah serbuan bangsa Mongol ke Baghdad, muncul generasi taqlid, ijtihad tertutup, orang saleh, wali sufi dan tokoh tarikat yang sudah wafat diminta syafaatnya, sehingga menghilangkan etika dan etos kerja umat Islam yang sedang lemah.Keadaan seperti ini terus berkepanjangan, pada-bal di belahan dunia sebelah Barat sedang muncul ke-bangkitan yang maha dahsyat sebagai hasil kebangkitan kembali, renaisance dan age of reason, enlightenment, masa terjadinya pencerahan terhadap akal pemikiran atau masa penceraban, terutama tabun 1650-1800 M. ${ }^{16}$

Berkaitan dengan hal di atas, dalam hal ini penulis ingin melihat aktualisasi nilai-nilai Islam serta kebijakannya dalam merevitalisasi pemahaman moderasi terhadap ajaran keislaman di lembaga pendidikan Islam yang di terapkan oleh beberapa perguruan tinggi Islam mengenai studikeislaman.Dan dalam tulisan inipenulis ingin menjadikannya sebagai tambahan serta reflksi kita bersama, mengenai beberapa temuan teori yang dihasilkan oleh para sarjana barat dalam melihat Islam di Indonesia.Untuk selanjutnya dalam tulisan diharapkan bisa mengapresiasi bahkan mengkritisi beberapa temuan mereka.Karena setelah mereka melakukan pendidikan secara intensif, ternyata banyak hal yang harus dan bisa dijelaskan secara ilmiah mengenai ke-khasan dan corak keIslaman di Indonesia.

\section{b. Praksis Nilai-Nilai Islam Pada Lembaga Pendidikan}

Praksis nilai-nilai pendidikan Islam pada lembaga pendidikan harus terpatri dalam sebuah tindakan.Namun sebelum melihat lebih jauh nilai-nilai yang harus ada dalam dimensi pendidikan, terlebih dahulu kita mengurai nilai itu sendiri.Nilai Menurut Milton Rokeach dan James Bank, adalah suatu tipe kepercayaan yang berada dalam ruang lingkup sistem kepercayaan yang mana seseorang bertindak atau menghindari suatu tindakan, atau mengenai sesuatu yang pantas atau tidak pantas dikerjakan. ${ }^{17}$ Menurut Sidi Gazalba adalah sesuatu yang bersifat abstrak, ia ideal, nilai bukan benda konkrit, bukan fakta, tidak hanya persoalan benar dan salah dan menurut pembuktian empirik, melainkan soal penghayatan yang dikehendaki dan tidak dikehendaki, disenangi dan tidak disenangi. Nilai-nilai Islam itu pada hakikatnya adalah kumpulan dari prinsipprinsip hidup, ajaran-ajaran tentang bagaimana manusia seharusnya menjalankan kehidupannya di dunia ini, yang satu prinsip dengan lainnya saling terkait membentuk

${ }^{16}$ Harun Nasution, Islam Ditinjau Dari Berbagai Aspeknya, (Jakarta ,UI Press, 1986), blm. 93.

${ }_{17}$ Chabib Thoha, Kapita Selekta Pendidikan Islam, (Yogyakarta: Pustaka Pelajar, 1996), hlm. 60-61. 
satu kesatuan yang utuh tidak dapat dipisah-pisahkan.Yang terpenting dengan wujud nilai-nilai Islam harus dapat ditransformasikan dalam lapangan kehidupan manusia.Hal tersebut ejalan dengan karakteristik Islam sebagaimana diungkapkan oleh Muhammad Yusuf Musa berikut ini.'Yaitu mengajarkan kesatuan agama, kesatuan politik, kesatuan sosial, agama yang sesuai dengan akal dan fikiran, agama fitrah dan kejelasan, agama kebebasan dan persamaan, dan agama kemanusiaan.'Lapangan kehidupan manusia harus merupakan satu kesatuan antara satu bidang dengan bidang kehidudpan lainnya.Dalam pembagian dimensi kehidupan Islam lainnya yaitu ada dimensi tauhid, syariah dan akhlak, namun secara garis besar nilai Islam lebih menonjol dalam wujud nilai akhlak. ${ }^{18}$

Menurut Abdullah Darraz sebagaimana dikutip Hasan Langgulung, membagi nilainilai akhlak kepada lima jenis:

a. Nilai-nilai Akhlak perseorangan

b. Nilai-nilai Akhlak keluarga

c. Nilai-nilai Akhlak sosial

d. Nilai-nilai Akhlak dalam Negara

e. Nilai-nilai Akhlak agama

Macam-macam nilai sangatlah kompleks dan sangat banyak, maka dari itu dapat dilihat dari berbagai sudut pandang. Dilihat dari sumbernya nilai dapat diklasifikasikan menjadi dua macam, yaitu:

a. Nilai Ilahiyah (nash) yaitu nilai yang lahir dari keyakinan (belief), berupa petunjuk dari supernatural atau Tuhan. Dibagi atas tiga hal:

1) Nilai Keimanan (Tauhid/Akidah)

2) Nilai Ubudiyah

3) Nilai Muamalah

b. Nilai Insaniyah (Produk budaya yakni nilai yang lahir dari kebudayaan masyarakat baik secara individu maupun kelompok) yang terbagi menjadi tiga:

1) Nilai Etika

2) Nilai Sosial

3) Nilai Estetika

Kemudian dalam analisis teori nilai dibedakan menjadi dua jenis nilai pendidikan yaitu:

a. Nilai instrumental yaitu nilai yang dianggap baik karena bernilai untuk sesuatu yang lain.

b. Nilai instrinsik ialah nilai yang dianggap baik, tidak untuk sesuatu yang lain melainkan didalam dan dirinya sendiri.

Sedang macam-macam Nilai Menurut Notonagoro:

${ }_{18}$ Muhaimin dan Abdul Mujib, Pemikiran Pendidikan Islam: Kajian Filosofis dan Kerangka Dasar Oprasionalnya, (Bandung: Trigenda Karya 1993), hlm. 111

Copyright (C2020 Schemata Journal

Available online at http:/ /journal.uinmataram.ac.id/index.php/schemata 
a. Nilai Material adalah segala sesuatu yang berguna bagi unsur manusia.

b. Nilai Vital adalah segala sesuatu yang berguna bagi manusia untuk dapat mengandalkan kegiatan atau aktivitas.

c. Nilai Kerohanian adalah segala sesuatu yang berguna bagi rohani manusia. Nilai Kerohanian dibedakan atas empat Macam;

d. Nilai Kebenaran atau kenyataan, yakni bersumber dari unsur akal manusia (Nalar, Ratio, Budi, Cipta)

e. Nilai Keindahan, yakni bersumber dari unsur rasa manusia (Perasaan, Estetika)

f. Nilai Moral atau Kebaikan, yakni bersumber dari unsur kehendak atau kemauan (Karsa, etika)

g. Nilai Religius, yakni merupakan nilai ketuhanan, kerohanian yang tinggi, dan mutlak yang bersumber dari keyakinan atau kepercayaan manusia.

Islam memandang adanya nilai mutlak dan nilai intrinsik yang berfungsi sebagai pusat dan muara semua nilai. Nilai tersebut adalah tauhid (uluhiyah dan rububiyah) yang merupakan tujuan semua aktivitas hidup muslim. Semua nilai-nilai lain yang termasuk amal shaleh dalam Islam termasuk nilai instrumental yang berfungsi sebagai alat dan prasarat untuk meraih nilai tauhid.Dalam praktek kehidupan nilai-nilai instrumental itulah yang banyak dihadapi oleh manusia. Seperti perlunya nilai-nilai yang tercantum dalam program LVEP (Living V alues An Education Program) yang ada dua belas nilai-nilai kunci diantaranya:

a. Kedamaian

b. Penghargaan

c. Cinta

d. Toleransi

e. Tanggung jawab

f. Kebahagian

g. Kerja sama

h. Kerendahan hati

i. Kejujuran

j. Kesederhanaan

k. Kebebasan

1. Persatuan. ${ }^{19}$

Sebagaimana telah dijelaskan dalam pengertian tentang nilai- nilai pendidikan Islam di atas bahwa nilai menunjukan sesuatu yang terpenting dalam keberadaan manusia atau suatu yang paling berharga atau asasi bagi manusia, oleh karena itu bila dilihat dari pendidikan Islam nilai merupakan jalan hidup yang berproses pada wilayah ritual dan berdimensi eskatologisdiajarkan perlunya penghayatan nilai- nilai ketuhanan.

${ }^{19}$ Mansur Isna, Diskursus Pebdidikan Islam, (Yogyakarta: Global Pustaka Utama, 2001), hlm. 99. 
Disinilah manusia memberlukan bimbingan serta tata cara ibadah yang baik, berdoa yang benar, berperilaku yang baik dan sebagainya.

Tahap-tahap proses pembentukan nilai menurut Karthwohl sebagaimana dikutip oleh Mawardi Lubis lebih banyak banyak ditentukan dari arah mana dan bagaimana seseorang menerima nilai-nilai dari luar kemudian menginternalisasikan nilai-nilai tersebut dalam dirinya. Menurut Karthwohl proses pembentukan nilai dapat dikelompokan menjadi 5 tahap, yaitu :

a. Tahap receiving ( menyimak). Pada tahap ini seseorang secara aktif dan sensitif menerima stimulus dan menghadapi fenomena-fenomena, sedia menerima secara aktif dan selektif dalam memilih fenomena.

b. Tahap responding ( menanggapi ). Pada tahap ini seseorang sudah dalam bentuk respons yang nyata.

c. Tahap valuing ( memberi nilai ). Jika tahap pertama dan kedua lebih bersifat aktvitas fisik biologis dalam menerima dan menanggapi nilai, maka pada tahap ini seseorang sudah mampu menangkap stimulus itu atas dasar nilai-nilai yang terkandung di dalamnya dan mulai mampu menyusun persepsi tentang objek.

d. Tahap mengorganisasikan nilai ( organization), yaitu satu tahap yang lebih kompleks dari tahap ketiga di atas. Seseorang mulai mengatur sebuah sistem nilai yang ia dari luar untuk diorganisasikan (didata) dalam dirinya sehingga sistem nilai itu menjadi bagian yang tidak terpisahkan dalam dirinya.

e. Tahap karakterisasi nilai ( characterization), yang ditandai dengan ketidakpuasan seseorang untuk mengorganisir sistem nilaiyang diyakininya dalam kehidupan secara mapan, ajek dan konsisten. ${ }^{20}$

Adapun sumber Nilai-nilai Pendidikan Islamyang menjadi acuan hidup manusia amat banyak macamnya, semua jenis nilai memiliki sumber yang menjadi pengikat semua nilai. Sumber nilai-nilai pendidikan Islam yang menjadi acuan bagi hidup manusia adalah sumber nilai Islam. Sumber nilai Islam yang dimaksud berasal dari nilai yang menjadi falsafah hidup yang dianut oleh pelaku pendidikan Islam, sumber nilai agama yang pokok adalah Al- Qur'an dan As- Sunnah.

a. Al- Qur'an

Menurut Zakiah Daradjat Al- Qur'an adalah firman Allah berupa wahyu yang disampaikan oleh malaikat jibril kepada Nabi Muhammad Saw. Pengertian tentang Al- Qur'an di atas diperkuat dengan pendapat dari Allamah Syayyid bahwa Al-Qur'an terdiri dari serangkaian topik teoritis dan praktis sebagai pedoman hidup untuk umat manusia. Apabila semua ajaran tersebut dilaksanakan, kita akan memperoleh kebahagiaan di dunia dan di akhirat. Al-

${ }^{20}$ Mohammad Nor Syam, Pendidikan Filsafat dan Dasar Filsafat Pancasila, (Surabaya: Usaha Nasional, 1986), hlm. 137. 
Qur'an merupakan sumber nilai yang pertama dan utama, yang eksistensinya tidak mengalami perubahan, walaupun interpretasinya mengalami perubahan, sesuai dengan konteks zaman, keadaan dan tempat.

Kedudukan Al- Qur'an dalam nilai-nilai pendidikan Islam adalah sebagaisumber etika dan nilai-nilai yang paling shahih dan kuat, karena ajaran AlQur'an adalah bersifat mutlak dan universal. Baik yang isinya menganjurkan atau perintah dan juga berisi nilai-nilai yang mengandung larangan. Nilai-nilai Qur'ani secara garis besar terdiri dari dua nilai yaitu nilai kebenaran (metafafisis dan saintis) dan nilai moral. Kedua nilai ini akan memandu manusia dalam membina kehidupan dan penghidupannya.

b. As- Sunnah

As- Sunnah merupakan sumber ajaran kedua sesudah Al- Qur'an. As-Sunnah ialah perkataan, perbuatan ataupun pengakuan Rasul Allah SWT. Jadi Sunnah Rasul, adalah amalan yang dikerjakan oleh Rasulullah SAW. Dalam proses perubahan hidup sehari-hari dan menjadi sumber utama. Sunnah berisi petunjuk ( pedoman ) untuk kemaslahatan hidup manusia dalam segala aspeknya, untuk membina hubungan antar umat manusia menjadi manusia sutuhnya atau umat muslim yang bertakwa. Ssunnah dijadikan sumber utama karena Allah SWT menjadikan Muhammad sebagai tauladan bagi umatnya. Firman Allah dalam surat Al- Ahzab ayat 21 yang berbunyi:

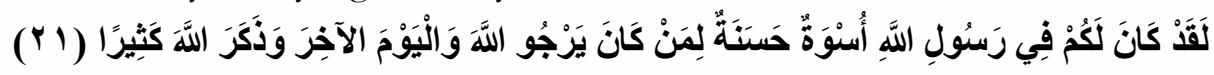
"Sesunggubnya telah ada pada (diri) Rasulullah itu suri tauladan yang baik bagimu (yaitu) bagi yang mengharap (rahmat) Allah dan (kedatangan) hari kiamat dan dia banyak menyebut Allah "(QS. Al-Abzab: 21)

Adapun nilai-nilai praksis yang ada dalam pendidikan islam yakni Pendidikan ibadah yang berkaitan dengan muamalah yang meliputi:

a) Pendidikan Syakhsiyah. Pendidikan Syakhsiyah merupakan pendidikan yang memuat perilaku individu, seperti masalah perkawinan, hubungan suami istri dan keluarga yang bertujuan untuk membentuk keluarga yang sakinah dan sejahtera.

b) Pendidikan Madaniyah. Pendidikan ini berkaitan dengan perdangan seperti upah, gadai yang bertujuan untuk mengelola harta benda atau hak-hak indvidu.

c) Pendidikan Jana'iyah. Pendidikan ini yang berhubungan denganpidana atas pelanggaran yang dilakukan, yang bertujuan memlihara kelangsungan kehidupan manusia, baik berkaitan dengan harta, kehormatan, maupun hakhak individu yang lain. 
d) Pendidikan Murafa'at. Pendidikan ini berhubungan dengan acara seperti peradilan, saksi maupun sumpah yang bertujuan untuk menegakkan keadilan diantara anggota masyarakat.

e) Pendidikana Dusturiyah. Pendidikan ini berhubungan dengan undangundang Negara yang mengatur hubungan rakyat dengan pemerintah yang bertujuan untuk stabilitas bangsa.

f) Pendidikan Duwaliyah. Pendidikan ini yang berhubungan dengan tata negara seperti tata negara Islam, tata negara tidak Islam, wilayah perdamaian dan wilayah perang, dan hubungan muslim di negara lain yang bertujuan untuk perdamaian dunia.

g) Pendidikan Iqtishadiyah. Pendidikan ini berhubungan dengan perkonomian individu dan negara, hubungan yang miskin dengan yang kaya yang bertujuan untuk keseimbangan dan pemerataan pendapatan. ${ }^{21}$

\section{c. Praksis Kebijakan Pemerintah Pada Lembaga Pendidikan Islam}

Dalam Dictionary of Politics and Government disebutkan bahwa kebijakan adalah sebuah detail rencana tentang bagaimana sesuatu dilakukan. Menurut JE. Hosio, kebijakan dapat dipahami sebagai suatu arah tindakan yang bertujuan, yang dilaksanakan oleh pelaku kebijakan di dalam mengatasi suatu masalah atau urusan-urusan yang bersangkutan. Menurut Harold Laswell dan Abraham Kaplan mendefinisikan kebijakan publik sebagai suatu program yang diproyeksikan dengan praktik tertentu. Menurut Jenkins, kebijakan adalah serangkaian keputusan yang saling terkait...berkenaan dengan pemilihan tujuan-tujuan dan cara-cara untuk mencapainya dalam situasi tertetntu. Menurut James Anderson, kebijakan publik merupakan serangkaian kegiatan yang mempunyai maksud/tujuan tertentu yang diikuti dan dilaksanakan oleh seorang aktor atau sekelompok aktor yang berhubungan dengan suatu permasalahan atau suatu hal yang diperhatikan. Sedangkan Thomas R. Dye, mendefinisikan kebijakan publik sebagai segala sesuatu yang dikerjakan pemerintah, mengapa mereka melakukan, dan hasil yang membuat sebuah kehidupan bersama tampil berbeda.Dan David Easton mendefinisikannya sebagai akibat dari aktivitas pemerintah.Selain hal di atas, yang sangat penting untuk dipahami bahwa setiap kebijakan publik berisi desain -kerangka ide dan instrument- untuk diidentifikasi dan dianalisis. ${ }^{22}$

Kerangka ini menempatkan desain kebijakan sebagai struktur kelembagaan yang terdiri dari unsur-unsur yang dapat diidentifikasi: tujuan, kelompok sasaran, agen, struktur pelaksanaan, alat, aturan, dasar pemikiran, dan asumsi. Kraft dan Furlong

21 Achmadi, Ideologi Pendidikan Islam Paradikma Humanisme Teosentris, cet. 1, (Yogyakarta: Pustaka Pelajar, 2005), hlm. 121-122.

22JE. Hosio, Kebijakan Publik dan Desentralisasi (Yogyakarta: LBM, 2006), 3. Lihat Arif Rohman dan Teguh Wiyono, Education Policy in Decentralization (Yogyakarta: Pustaka Pelajar, 2010), hlm. 2. 
mendefinisikan kebijakan publik sebagai sebuah tindakan pemerintah (atau tindakan) mengambil dalam menanggapi masalah sosial.Masalah sosial adalah kondisi yang masyarakat anggap luas tidak dapat diterima dan oleh karena itu memerlukan intervensi. Selanjutnya Riant Nugroho menjelaskan bahwa kebijakan publik disyaratkan harus memenuhi enam hal, yaitu: (1) terkait dengan setiap aturan main dalam kehidupan bersama; (2) berkaitan dengan bagaimana perkejaan itu dirumuskan, ditetapkan, dan dinilai hasilnya; (3) menyangkut sesuatu yang dikerjakan atau tidak dikerjakan; (4) menyangkut siapa pemerintah dan kenapa harus pemerintah; (5) mengatur kehidupan bersama atau kehidupan publik, dan bukan mengatur kehidupan orang seorang atau golongan; (6) manfaat yang diperoleh oleh masyarakat yang bukan pengguna langsung dari produk (kebijakan) yang dihasilkan jauh lebih banyak atau lebih besar dari pengguna langsungnya.

Konsep ini yang disebut konsep public goods.Ide kabijakan publik mengandung anggapan bahwa ada suatu ruang atau domain dalam kehidupan yang bukan privat atau murni individual, tetapi milik bersama atau milik umum.Publik itu sendiri berisi aktivitas manusia yang dipandang perlu untuk diatur atau diintervensi oleh pemerintah atau aturan sosial, atau setidaknya oleh tindakan bersama.Sesuai dengan konteks penelitian ini, yakni kebijakan pemerintah provinsi, maka penulis memiliki kecenderungan untuk menggunakan pengertian kebijakan yang menunjukkan bahwa kebijakan adalah serangkaian rencana untuk dilaksanakan yang diputuskan oleh pemerintah untuk menyelesaikan masalah yang dihadapi oleh masyarakat.Oleh karena itu, maka menurut penulis kebijakan pendidikan adalah serangkaian rencana untuk dilaksanakan yang diputuskan oleh pemerintah untuk menyelesaikan masalah yang dihadapi oleh masyarakat dalam bidang pendidikan.Sehingga, jika dibutuhkan pengertian kebijakan pendidikan Islam, berarti ada pengkhususan bidang dari kebijakan itu ialah pendidikan Islam. Terkait dengan pengertian yang telah penulis ambil tentang kebijakan pendidikan Islam ini, dapat dipahami bahwa ruang lingkup kebijakan pendidikan Islam meliputi, tujuan pendidikan Islam, kurikulum pendidikan Islam, tenaga pendidik dan kependidikan, sarana dan prasarana, evaluasi, manajemen, PAI di sekolah, lembaga pendidikan madrasah, dan lain sebagainya yang tetap memiliki relevansi dengan pendidikan Islam. ${ }^{23}$

Kebijakan Pendidikan Islam dalam UU Nomor20 Tahun2003 Pengaturan berdasarkan UU terhadap pelaksanaan pendidikan agamadi Indonesia, khususnya terhadap pelaksanaan pendidikan agama Islam, kualitasnya memiliki grafik yang turun naik dari masa ke masa. Dari sudut pandang ilmu hukum yang mengatur materi pendidikan agama dalam undang-undang memang sangat terasa nuansa pertarungan

23 Riant Nugroho, Public Policy: Teori, Manajemen, Dinamika, Analisis, Konvergensi, dan Kimia Kebijakan, (Jakarta: Elex Media Komputindo, 2014), hlm. 125. 
kepentingan ideologi dari berbagai kelompok masyarakat.Paling tidak, ada tiga kelompok yang paling dominan dalam mempengaruhi lahirnya berbagai UU dan peraturan yang berkaitan dengan pendidikan.Baik dari kelompok politik, kelompok ekonomi dan bisnis, maupun dari berbagai kelompok keyakinan agama tertentu.Nuansa pertarungan kepentingan ideologi juga tetap muncul.Pada masa pemerintahan rezim Soekarno masih berkuasa, terjadi pertarungan antara kepentingan ideologi komunis, nasionalis sekulerdan kelompok agama Islam."Tiga kekuatan ideologis ini sering kali berbenturan dan saling mengalahkan.

Presiden Soekarno adalah tokoh yang menganut ideologi nasionalis yang berbasis ke Indonesiaan dan kultural.Dalam posisinya itu, ia terkadang dekat dengan kelompok Islam dan terkadang dekat dengan kelompok sekularis-komunis."Barulah pada akhir tahun sembilan puluhan Pemerintah Orde Baru melahirkan UU No.2 tahun1989tentangsistempendidikannasional, walaupun harus melaluiperdebatan sengit baik di parlemen maupun di tengah-tengah masyarakat.Perdebatan yang paling dominan adalah mengenai masuknya pendidikan agama dalam UU.Umat Muslim memperjuangkan pendidikan agama masuk dalam UU, sedangkan kelompok nasionalis sekuler menolaknya.Perdebatan panjang terhadap Rencana UU sistem pendidikan nasional ini adalah sebagai refleksi sikap umat Islam terhadap posisi pendidikan Islam yang diabaikan oleh UU No. 4 tahun1950.Karena UU tersebut tidak memihak kepada pendidikan Islam, sehingga isu-isu pendidikan agama selalu diperdebatkan dan menjadi perbincangan masyarakat.Harus diakui bahwa akumulasi dari perdebatan panjang yang melelahkan ini memberikan pengaruh terhadapisi UU NO.2 tahun1989 sebagai UU Sistem Pendidikan Nasional"jilid dua" yang disahkan pada tanggal27 Maret1989.Terutama masalah isiUU yang menyangkut dengan permasalahan kewajiban mengikuti pelaksanaan pendidikan agama.DalamUU yang muncul39 tahun kemudian dariUU pertama ini, pendidikan keagamaan dan pendidikan agama mulai mendapat tempat yang cukup signifikan dibandingkan denganUU yang sebelumnya.

Undang-undang SistemPendidikan Nasional ini akhirnya menetapkan pendidikan agama sebagai salah satu unsur inti dalam kurikulum nasional dan wajib dimuat dalam setiap jenis, jalur dan jenjang pendidikan.Pada pasal4 Undangundang Nomor2 Tahun1989 ini, menetapkan keimanan dan ketakwaan sebagai bagian yang harus dicapai dalam tujuan pendidikan nasional.Keimanan dan ketakwaan adalah terminologi yang sangat identik dan akrab dengan pendidikan agama dan keagamaan. Untuk itu pada pasal11 ayat1 dan6, dan pasal15 ayat2 menetapkan bahwa pendidikan keagamaan diakui sebagai salah satu jalur pendidikan sekolah. Kemudian pada pasal 39 ayat2 dan3, menetapkan bahwa dalam penyusunan kurikulum, pendidikan agama menjadi mata pelajaran wajib dalam setiap jenis, jalur dan jenjang pendidikan.Selain itu pasal10 juga menetapkan, bahwa pendidikan keluargayang merupakan bagian dari jalur pendidikan 
luar sekolah, juga harus memberikan keyakinan agama, di samping nilai budaya, nilai moral dan keterampilan.Adapun penerimaan seseorang sebagai peserta didik tidak boleh dibedakan berdasarkan keyakinan agama, sebagaimana diatur dalam pasal7.

Dengan ditetapkannya UU No.2 Tahun1989 tentang Sistem Pendidikan Nasional beserta peraturan turunannya, seperti Peraturan Pemerintah Nomor 28 Tahun 1990 tentang Pendidikan Dasar, dan Peraturan Pemerintah Nomor 29 Tahun 1990 tentang Pendidikan Menengah, menjadikan pendidikan Islam terintegrasi secara kuat dalam sistem pendidikan nasional. Namun, di tengah masyarakat akhirnya terjadi polemik, karena sekolah yang diselenggarakan oleh yayasan atau badan hukum dengan berciri khas berdasarkan agama tertentu, tidak diwajibkan menyelenggarakan pendidikaan agama lain dari agama yang menjadi ciri khas lembaga pendidikan tersebut. "Inilah poin pendidikan yang kelak menimbulkan polemik dan kritik dari sejumlah kalangan, di mana para pelajar dikhawatirkan akan pindah agama (berdasarkan agama yayasan/sekolah), karena mengalami pendidikan agama yang tidak sesuai dengan agama yang dianutnya."Perkembangan selanjutnya, rezim pemerintahan orde Reformasi merevisi UU No. 2 Tahun1989 tentang sistem pendidikan nasional dengan mengusulkan UUbaru, karena menganggap bahwa UU No.2 tahun1989 sudah tidak sesuai dengan perkembangan zaman. Sementara saat akan diundangkannya Rencana UU sistem pendidikan nasional yang baru sebagai pengganti UU yang lama terjadi juga kontroversi dan perdebatan yang sangat tajam di tengah masyarakat. Terutama yang dianggap paling kontroversial adalah ketentuan yang menyatakan bahwa "setiap peserta didik berhak mendapatkan pendidikan agama sesuai dengan agama yang dianut dan diajarkan oleh pendidik yang seagama."Substansi yang ditentang umumnya adalah pasal yang berisi keharusan sekolah-sekolah swasta menyediakan guru agama yang seagama dengan peserta didik.Mereka memberi alasan bahwa pasal ini menimbulkan konsekuensi tambahan biaya terhadap lembaga-lembaga penyelenggara pendidikan baik Kristen maupun Islam.Karena mereka harus merekrut guru-guru agama sesuai dengan berbagai keyakinan agama yang dianut oleh anak-anak muridnya.UU No.20 Tahun2003 akhirnya disahkan dan ditandatanganioleh Presiden Megawati SoekarnoPutri pada tanggal8 Juli2003.

Sebagaimana diatur pada pasal 4, secara garis besar isi dari UU No.20 Tahun2003 tentang Sistem Pendidikan Nasional ini memberikan penekanan bahwa prinsip penyelenggaraan pendidikan harus dilaksanakan secara demokratis dan berkeadilan serta tidak diskriminatif dengan menjunjung tinggi hak asasi manusia, nilai keagamaan, nilai kultural, dan kemajemukan bangsa. Pendidikan diselenggarakan sebagai satu kesatuan yang sistemik dengan sistem terbuka dan multi makna. Selain itu, pendidikan diselenggarakan sebagai suatu proses pembudayaan dan pemberdayaan peserta didik yang berlangsung sepanjang hayat, dengan memberi keteladanan, membangun kemauan, 
dan mengembangkan kreativitas peserta didik dalam proses pembelajaran; dengan mengembangkan budaya membaca, menulis, dan berhitung bagi segenap warga masyarakat, dan dengan memberdayakan semua komponen masyarakat melalui peran serta dalam penyelenggaraan dan pengendalian mutu layanan pendidikan. UU ini pada pasal 13 menetapkan bahwa pendidikan nasional dilaksanakan melalui jalur formal, non formal, dan informal yang penyelenggaraannya dapat saling melengkapi dan saling memperkaya.Jenjang pendidikan formal terdiri atas pendidikan dasar, pendidikan menengah, dan pendidikan tinggi.Jenis pendidikan mencakup pendidikan umum, kejuruan, akademik, profesi, vokasi, keagamaan, dan khusus.Menetapkan pendidikan agama sebagai salah satu unsur inti dalam kurikulum nasional dan wajib dimuatdalam setiap jenis, jalur dan jenjang pendidikan. UU No.20 Tahun2003ini juga menetapkan dalam pasal3, bahwa keimanan dan ketakwaan adalah sebagai bagian yang harus dicapai dalam tujuan pendidikan nasional. Sedangkan pada pasal15 menetapkan bahwa pendidikan keagamaan diakui sebagai salah satu jalur dan jenis pendidikan.

Akan tetapi pertanyaannya, bagaimanakah praksis kebijakan pendidikan Islam pada lembaga pendidikan di Indonesia.Dari beberapa uraian kebijakan pemerintah mengenai sistem pendidikan Islam di Indonesia masih sangat kurang dan masih kental nuansa politis dalam suatu kebijakan pendidikan Islam. Hal ini bisa dilihat dari tujuan pendidikan nasional misalnya "untuk berkembangnya potensi agar menjadi manusia yang beriman dan bertakwa kepada Tuhan Yang Maha Esa, berakhlak mulia, sehat, berilmu, cakap, kreatif, mandiri, dan menjadi warga negara yang demokratis serta bertanggung jawab." Kemudian dalam pasal 37, menyatakan bahwa "kurikulum pendidikan dasar dan menengah,serta kurikulum pendidikan tinggi, wajib memuat pendidikan agama."Akan tetapi isi pasal 37 ini sangat paradoks dengan ketentuan yang diatur dalam pasal 12. Dalam pasal 12 menetapkan bahwa "setiap peserta didik pada setiap satuan pendidikan berhak: mendapatkanpendidikan agama sesuai dengan agama yang dianutnya dan diajarkan oleh pendidik yang seagama."

Ketentuan kedua hal tersebut di atas, bila dianalisa maka penyelenggara pendidikan, yaitu orang tua, masyarakat dan pemerintah pusat maupun pemerintah daerah, dalam menyelenggarakan pendidikan wajib mencantumkan dalam setiap kurikulum pendidikannya materi pendidikan keislaman atau agama secara umum.Tetapi secara berlawanan peserta didik tidak wajib mengikuti pelajaran pendidikaan agama sebagaimana diatur dalam pasal 12.Ketentuan pasal ini bertentangan dengan Pancasila, Pembukaaan dan isi pasal 29 UUD Negara Republik Indonesia Tahun 1945. Demikian juga halnya dengan ketentuan pasal4 UU Sistem Pendidikan Nasional yang mensejajarkan kedudukan agama dengan nilai-nilai kultural atau budaya, bangsa dan ketentuan pasal15 yang melakukan dikotomi antara pendidikan agama dengan 
pendidikan umum, sertaketentuan pasal 36 dan 37 tentang isi dan pengertian kurikulum pendidikan islam/agama.

Berdasarkan kajian ini, ditemukan bahwa adanya proses politik sekularisasi pendidikan yang masuk dalam sistem pendidikan nasional serta keislaman di Indonesia. Hal itu dapat dilihat dalam UU No.20 tahun 2003 tentang Sistem Pendidikan Nasional.Apabila dikaji secara kritis, politik pendidikan sekuler di Indonesia telah masuk dalam rumusan undangundang tersebut.Sekadar contoh, dari keenam ayat yang mengatur prinsip penyelenggaran pendidikan sebagaimana diatur dalam undang-undang tersebut, prioritas pertama yang harus dijunjung tinggi dalam penyelenggaraan pendidikan adalah hak asasi manusia.Kedudukan nilai-nilai agama bahkan tidak boleh berbenturan dengan nilai-nilai hak asasi manusia, dan nilai keagamaan sejajar susunannya dengan nilai-nilai kultural, padahal seharusnya kedudukan agama harus lebih tinggi dari hanya sekadar hak asasi manusia. Selain itu, apabila ditelaah beberapa ketentuan dalam UU No. 20 Tahun 2003, didapati banyak isinya yang tidak selaras, bertentangan antara satu ayat dan pasal dengan ayat dan pasal lain, bahkan bertentangan dengan sistem pendidikan Islam dan UUD 1945. Sebab itu, undang-undang tersebut perlu direvisi agar sesuai dengan ajaran agama mayoritas di Indonesia sehingga mampu selaras dengan pluralisme dan multikulturalisme di nusantara.

\section{KESIMPULAN}

Berdasarkan pembahasan pada bab sebelumnya dan merujuk pada tujuan penelitian, maka dapat disimpulkan bahwa Masuknya intoleransi dinilai masuk dari tiga pintu. Pertama, guru. Pemahaman guru sering menentukan cara bersikap dan bertindak siswa. Kedua, kurikulum yang masih dogmatis-doktriner, tidak memberikan ruang untuk berdialetika dan berimajinasi. Ketiga, kegiatan ekstra yang sarat dengan ideologi tertentu. Dalam konteks inilah, perlu kembali menyuarakan moderasi di sekolah. Sikap yang tidak ekstrim kanan, selalu menegasikan semuanya; juga tidak ekstrim kiri, menampung apapun dari luar; melainkan bersikap selektif-akomodatif. Mengajarkan sikap selektif-akomodatif kepada peserta didik, mendapat tantangan tersendiri. Belum lagi adanya kecenderungan cara beragama yang praktis, instan, dan tidak mau ribet, di satu sisi; di tambah penetrasi media sosial.

\section{DAFTAR PUSTAKA}

Achmadi, (2005). Ideologi Pendidikan Islam Paradikma Humanisme Teosentris, cet. 1, Yogyakarta: Pustaka Pelajar.

Sanusi, Anwar, (2016). Metodologi Penelitian Bisnis, Jakarta : Salemba Empat, h.32

Rohman, A. \& Wiyono, T. (2010). Education Policy in Decentralization. Yogyakarta: Pustaka Pelajar.

Thoha, Chabib, (1996). Kapita Selekta Pendidikan Islam, Yogyakarta: Pustaka Pelajar. 
Djamari, (1993) Agama dalam Perspektif Sosiologi, Bandung: Alfabeta.

Dzakiyyah, F. "Jenis Penelitian", (On-Line),tersedia dihttps://hidrosita.wordpress.com (5 Agustus 2017)

Nasution, H. (1986). Islam Ditinjau Dari Berbagai Aspeknya, Jakarta: UI Press

Hariyanto, I., (2015). Nalar islam Kontemporer Muhammed Arkoun, Tesis, Pascasarjana

UIN Sunan Kalijaga Yogyakarta.

Hosio, JE., (2006), Kebijakan Publik dan Desentralisasi, Yogyakarta: LBM

Nasution, K. (2012), Pengantar Studi Islam, Yogyakarta: ACadeMIA TAZZAFA

M.C. Riflecks, (1991), Sejarah Indonesia Modern, Yogyakarta: Gadjah Mada University Press

Mansur, I., (2001). Diskursus Pebdidikan Islam, Yogyakarta: Global Pustaka Utama

Syam, M. N., Pendidikan Filsafat dan Dasar Filsafat Pancasila, Surabaya: Usaha Nasional

Muhaimin, \& Mujib, A., (1993), Pemikiran Pendidikan Islam: Kajian Filosofis dan Kerangka Dasar Oprasionalnya, Bandung: Trigenda Karya.

Nugroho, R. (2014). Public Policy: Teori, Manajemen, Dinamika, Analisis, Konvergensi, dan Kimia Kebijakan, Jakarta: Elex Media Komputindo.

Sukardi, (2013), Metodologi Penelitian Pendidikan Kompetensi dan Praktiknya, Jakarata : PT Bumi Aksara,

Sujarweni, V. W., (2014). Metodologi Penelitian, Yogyakarta : Pustaka Baru Perss.

Zuhri, (2008), Studi Islam Dalam Tafsir Sosial Telaah Sosial Gagasan Keislaman Fą̧lur Rahman dan Mubammed Arkoun, Yogyakarta: Bidang Akademik UIN Sunan Kalijaga 